\title{
THE INFLUENCE OF THE TIME MR SEQUENCE PARAMETERS ON THE DIFFUSION WEIGHTED IMAGING SENSITIVITY
}

\author{
O. O. Naguliak, A. V. Netreba \\ Taras Shevchenko National University of Kyiv, Faculty of Radiophysics, Electronics and Computer Systems, \\ 60, Volodymyrska St., 01033, Kyiv, Ukraine \\ e-mail: olegrpd@ukr.net
}

(Received June 27, 2014; in final form - February 19, 2015)

\begin{abstract}
The Diffusion Weighted Imaging (DWI) reconstruction of tomograms with different time sequence parameters were considered. For the respective time parameters the sensitivity to diffusion weighting is found. Full reconstructed tomograms and fragments weighted with sensitivity parameters have been obtained. The reconstructed tomograms were weighted to sensitivity parameters filtered with the Gaussian matrix. The optimal sensitivity parameters for the DWI reconstruction have been proposed.
\end{abstract}

Key words: MRI, pulse sequence, DWI, proton density, reconstruction, tomograms, FID.

PACS number(s): 02.30.Nw, 02.70.-c, 42.30.Wb

\section{INTRODUCTION}

Today the Magnetic Resonance Imaging (MRI) is the most popular and effective instrument of human body investigation without invasive treatment [1]. The applied tasks of MRI for the visualization of spatial distribution of spin characteristics of biological objects have been investigated. The task solving problem is a result of the implementation of the magnetic-resonance techniques of a new generation. It gives an opportunity of receiving more informative diagnostic data which is required by the physical task solving of experimental conditions influence to free induction decay (FID). MRI has a wide range of applications in the medical diagnosis $[2,3]$. For obtaining an image in MRI, the signal is detected in the receiving system with parameters of signal sequence in the following form

$$
S\left(t_{x}, t_{y}\right)=\sum_{x, y} \rho(x, y) e^{i \gamma_{i}\left(B_{1} t_{x}+B_{2} t_{y}\right)} \exp \left(-t / T_{2}\right),
$$

where $S\left(t_{x}, t_{y}\right)$ is the detected signal, $\rho(x, y)$ is a proton density, $B_{1}$ and $B_{2}$ are magnetic fields and may be expressed consequently as $B_{1}=B_{0}+x G_{x}$ and $B_{2}=$ $B_{0}+y G_{y} ; \exp \left(-t / T_{2}\right)$ is the relaxation term determining the fading of a magnetization projection. Then for obtaining a tomogram $\rho(x, y)$ should be reconstructed; it is usually done with the help of the Fourier transformation [4]. The Diffusion MRI is a magnetic resonance imaging method that produces in vivo images of biological tissues weighted with the local microstructural characteristics of water diffusion [5]. In diffusion weighted imaging (DWI), each image voxel (three dimensional pixel) has an image intensity that reflects a single best measurement of the rate of water diffusion at that location [6]. This measurement is more sensitive to early changes after a stroke than more traditional MRI measurements such as $T_{1}$ or $T_{2}$ relaxation rates [7,8]. DWI is most applicable when the tissue of interest is dominated by isotropic water movement, e.g. $[9,10]$ grey matter in the cerebral cortex and major brain nuclei where the diffusion rate appears to be the same when measured along any axis [11]. By rearranging the formula for the signal loss due to the amount of diffusion to isolate the diffusion coefficient, it is possible to get an idea of the properties of diffusion occurring within a particular voxel (volume picture element) $[12,13]$.

$$
S(T E) / S_{0}=e^{-b D},
$$

where $S_{0}$ is the signal intensity without diffusion weighting, $S(T E)$ is the signal with the gradient, $b$ is the reconstruction parameter, $D$ is the diffusion coefficient. But it is possible to get a more accurate expression when taking the reconstruction parameter $b$ in the full form, where $b=-\gamma^{2} G^{2} \delta^{2}(\Delta-\delta / 3)$,

$$
\frac{S(T E)}{S_{0}}=e^{-\gamma^{2} G^{2} \delta^{2}(\Delta-\delta / 3) D} .
$$

Here, $S_{0}$ is the signal intensity without the diffusion weighting, $S(T E)$ is the signal with the gradient, $\gamma$ is the gyromagnetic ratio, $G$ is the strength of the gradient pulse, $\delta$ is the duration of the pulse, $\Delta$ is the time between the two pulses, and finally, $D$ is the diffusion coefficient.

\section{THE SENSITIVITY OF RECONSTRUCTION TO WATER DIFFUSION WEIGHTING}

The sensitivity of reconstruction to water diffusion weighting can be presented as follows

$$
\tilde{S}=\frac{S(T E)}{S_{0}} .
$$

Where $\tilde{S}$ is a sensitivity of reconstruction to water diffusion weighting, $S_{0}$ is the signal intensity without the diffusion weighting, $S(T E)$ is the signal with the gradient. 
The maximum sensitivity to water diffusion weighting is when $\partial \tilde{S} / \partial D=0$

$$
\frac{\partial \tilde{S}}{\partial D}=-\gamma^{2} G^{2} \delta^{2}\left(\Delta-\frac{\delta}{3}\right)
$$

$$
\exp \left[-\gamma^{2} G^{2} \delta^{2}\left(\Delta-\frac{\delta}{3}\right)\right]=0
$$

According to (5) and (6) the maximum meaning $\tilde{S}$ of sensitivity is when $\Delta \rightarrow \frac{\delta}{3}$, or $\left[\gamma^{2} G^{2} \delta^{2}\left(\Delta-\frac{\delta}{3}\right) D\right] \rightarrow \infty$

$$
\begin{gathered}
\frac{\partial \tilde{S}}{\partial \delta}=\exp \left(-\gamma^{2} G^{2} \delta^{2}\left(\Delta-\frac{\delta}{3}\right) D\right)\left[-2 \gamma^{2} G^{2} \delta\left(\Delta-\frac{\delta}{3}\right) D+\frac{1}{3} \gamma^{2} G^{2} \delta^{2} D\right]=0 \\
-2 \gamma^{2} G^{2} \delta\left(\Delta-\frac{\delta}{3}\right) D+\frac{1}{3} \gamma^{2} G^{2} \delta^{2} D=0-2\left(\Delta-\frac{\delta}{3}\right)+\frac{1}{3} \delta=0 \\
-2 \Delta+\frac{2 \delta}{3}+\frac{\delta}{3}=0 \\
2 \Delta=\delta
\end{gathered}
$$

The $\Delta$ is marked as a function of $\delta, \Delta=f(\delta)$. Thus, the sensitivity can be presented in the following way

$$
\tilde{S}=\frac{S(T E)}{S_{0}}=\exp \left(-\gamma^{2} G^{2} \delta^{2}\left(f(\delta)-\frac{\delta}{3}\right) D\right),
$$

Where $\Delta=f(\delta)=a_{0}+a_{1} \delta+a_{2} \delta^{2}$ is a function with the parameters $a_{0}, a_{1}, a_{2}$. The derivative should be presented as follows

$$
\begin{aligned}
& \frac{\partial \tilde{S}}{\partial \delta}=\exp \left(-\gamma^{2} G^{2} \delta^{2}\left[f(\delta)-\frac{\delta}{3}\right] D\right)\left(-\gamma^{2} G^{2} D \frac{\partial F(\delta)}{\partial \delta}\right) \\
& \frac{\partial F(\delta)}{\partial \delta}=\frac{\partial}{\partial \delta}\left\{\delta^{2}\left(f(\delta)-\frac{\delta}{3}\right)\right\}=2 \delta\left(f(\delta)-\frac{\delta}{3}\right)+\delta^{2}\left(\frac{\partial f}{\partial \delta}-\frac{1}{3}\right)=0
\end{aligned}
$$

$2 \delta\left(a_{0}+a_{1} \delta+a_{2} \delta^{2}-\frac{\delta}{3}\right)+\delta^{2}\left(a_{1}+2 a_{2} \delta-\frac{1}{3}\right)=0$

$\delta^{3}\left(2 a_{2}+2 a_{2}\right)+\delta^{2}\left(2\left(a_{1}-\frac{1}{3}\right)+a_{1}-\frac{1}{3}\right)+\delta\left(2 a_{0}\right)=0$,

$4 \delta^{2} a_{2}+2 \delta a_{1}+2 a_{0}=0$,

$2 \delta^{2} a_{2}+\delta a_{1}+a_{0}=0$.

The tables with possible time parameters and reconstruction sensitivity according to (11) for different values of $\delta$ and $\Delta$ which fit (13) are shown below.

\begin{tabular}{|c|c|c|c|c|}
\hline \multicolumn{5}{|c|}{$\delta=10 \mathrm{~ms}$} \\
\hline$a_{0}$ & $a_{1}$ & $a_{2}$ & $\Delta, \mathrm{ms}$ & $\tilde{S}$ \\
\hline 0 & -1 & 50 & 10 & 0.9935 \\
\hline-0.02 & 0 & 100 & 20 & 0.9834 \\
\hline 1 & -100 & 0 & 30 & 0.9737 \\
\hline-1 & 100 & 0 & 50 & 0.9544 \\
\hline
\end{tabular}

\begin{tabular}{|c|c|c|c|c|}
\hline \multicolumn{5}{|c|}{$\delta=20 \mathrm{~ms}$} \\
\hline$a_{0}$ & $a_{1}$ & $a_{2}$ & $\Delta$ & $\tilde{S}$ \\
\hline 0 & -4 & 100 & 20 & 0.9868 \\
\hline-0.08 & 0 & 100 & 40 & 0.9737 \\
\hline 2 & -100 & 0 & 60 & 0.9608 \\
\hline-2 & 100 & 0 & 80 & 0.9544 \\
\hline
\end{tabular}

Table 2. Time parameters of reconstruction sensitivity for $\delta=20 \mathrm{~ms}$.

\begin{tabular}{|c|c|c|c|c|}
\hline \multicolumn{5}{|c|}{$\delta=40 \mathrm{~ms}$} \\
\hline$a_{0}$ & $a_{1}$ & $a_{2}$ & $\Delta$ & $\tilde{S}$ \\
\hline 0 & -8 & 100 & 40 & 0.9640 \\
\hline$-0,16$ & 0 & 100 & 80 & 0.9355 \\
\hline 4 & -100 & 0 & 120 & 0.9506 \\
\hline-4 & 100 & 0 & 160 & 0.8991 \\
\hline
\end{tabular}

Table 1. Time parameters of reconstruction sensitivity for $\delta=10 \mathrm{~ms}$.

Table 3. Time parameters of reconstruction sensitivity for $\delta=40 \mathrm{~ms}$. 
For image filtration the Gaussian kernel is used. It is defined in the following way

$$
G_{2 \mathrm{D}}=(x, y, \sigma)=\frac{1}{2 \pi \sigma^{2}} e^{-\left(x^{2}+y^{2}\right) / 2 \sigma^{2}},
$$

where $\sigma$ determines the width of the Gaussian kernel. It is called standard deviation when we consider the Gaussian probability density function and $\sigma^{2}$ is the variance. The term $1 / 2 \pi \sigma^{2}$ in front of the one-dimensional Gaussian kernel is the normalization constant. With the normalization constant this Gaussian kernel is a normalized kernel, i. e. its integral over the full domain is unity for every $\sigma$. This means that increasing the $\sigma$ of the kernel reduces the amplitude substantially. The images of reconstructed tomograms with water diffusion weighted with $\tilde{S}$ sensitivity and filtered with the Gaussian kernel for different time parameters are shown below in Figs. 13 .

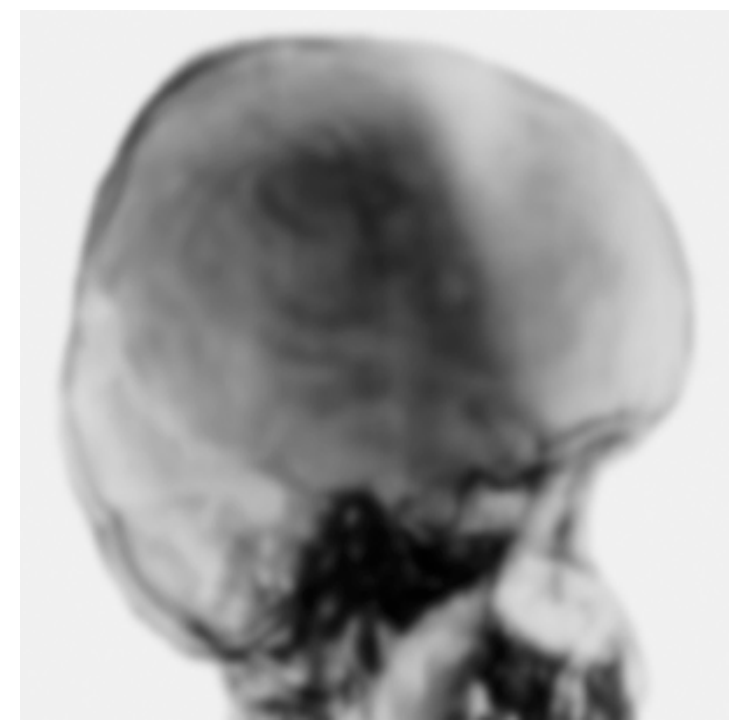

Fig. 1. The reconstructed tomogram with water diffusion.

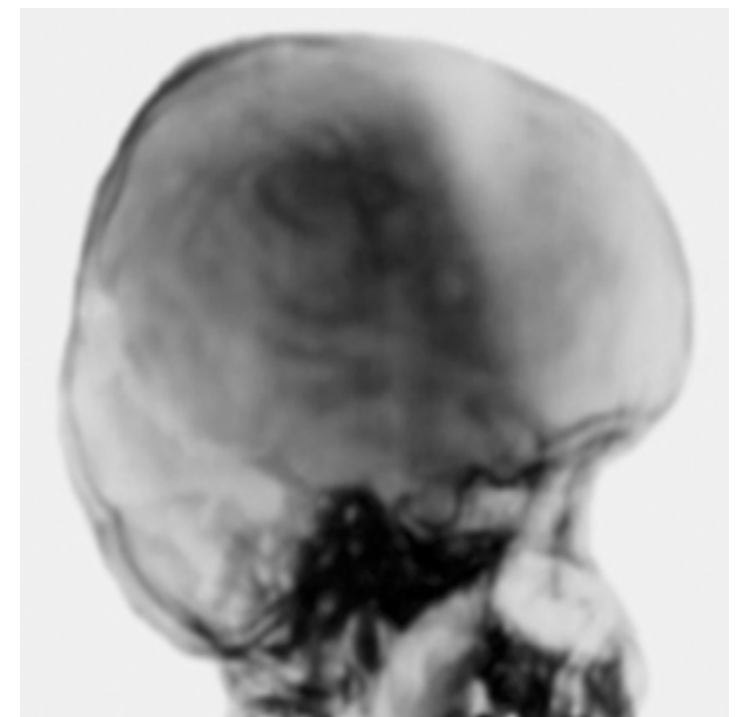

Fig. 2. The reconstructed tomogram weighted with 0.9544 sensitivity.

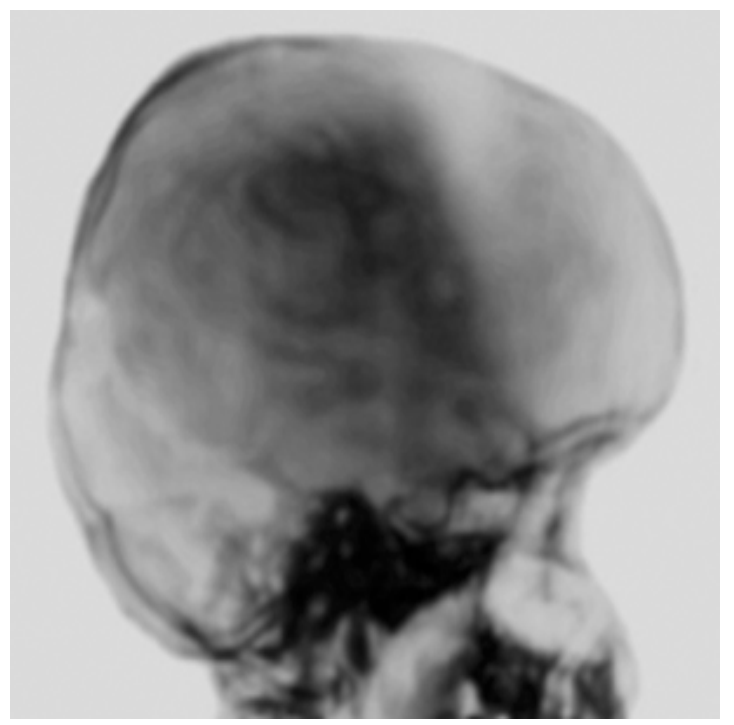

Fig. 3. The reconstructed tomogram weighted with sensitivity 0.9544 and filtered with the Gaussian kernel.

For more details the reconstructions of tomograms were obtained for a fragment of gradient line. The reconstructed tomograms are shown in Fig. 4.

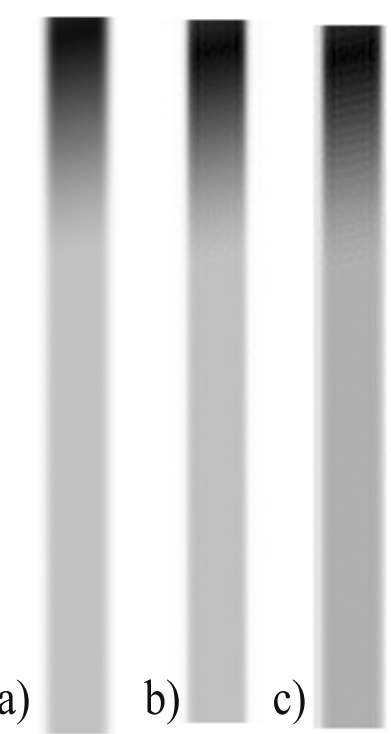

Fig. 4. The reconstructed fragments of tomogram: a with water diffusion; b - weighted with sensitivity 0.9544 ; c - weighted with sensitivity 0.9544 and filtered with the Gaussian kernel.

\section{CONCLUSION}

The method of reconciliation of time sequence parameters $\delta$ and $\Delta$ was proposed for more sensitive DWI. The obtained reconstructed tomograms weighted with sensitivity and filtered with the Gaussian matrix show that for obtaining more accurate and informative tomograms the MR sequence time parameters with the sensitivity exceeding 0.95 should be used. 
[1] D. E. Vaillancourt et al., Neurology 72, 1378 (2009).

[2] M. V. Kononov, A. V. Netreba, J. Phys. Stud. 11, 325 (2007).

[3] S. Posse, C. A. Cuenod, D. Le Bihan, Radiology 188, 719 (1993).

[4] M. V. Kononov, O. A. Nagulyak, A. V. Netreba, A. A. Sudakov, Radioelectron. Commun. Syst. 51, 531 (2008).

[5] J. Van Wedeen, P. Hagmann, W.-Y. I. Tseng, T. G. Reese, R. M. Weisskoff, Magn. Reson. Med. 54, 1377 (2005).

[6] E. O. Stejskal, J. E. Tanner, J. Chem. Phys. 42, 288 (1965).
[7] D. Le Bihan, Proc. Natl Acad. Sci. 103, 8263 (2006).

[8] A. V. Netreba, T. B. Pershina, S. P. Radchenko, in 2014 IEEE 34th International Conference on Electronics and Nanotechnology (ELNANO), p. 310.

[9] C. Liu, R. Bammer, M. E. Moseley, Israel J. Chem. 43, 145 (2003).

[10] J. H. Jensen, J. A. Helpern, A. Ramani, H. Lu, K. Kaczynski, Magn. Reson. Med. 53, 1432 (2005).

[11] V. J. Wedeen et al., NeuroImage 41, 1267 (2008).

[12] C. Lenglet et al., NeuroImage 45, 111 (2009).

[13] A. Netreba, O. Naguliak, M. Kononov, Visn. Kyiv Natl. Univ. Ser. Radiophys. Electron. 17, 46 (2012).

\title{
ВПЛИВ ЧАСОВИХ ПАРАМЕТРІВ МР-ПОСЛІДОВНОСТІ НА ЧУТЛИВІСТЬ ЗВАЖЕНОЇ ЗА ДИФУЗІЕЮ ВІЗУАЛІЗАЦІї
}

\author{
О. О. Нагуляк, А. В. Нетреба \\ Київсъкий начіональний університет імені Тараса Шевченка, \\ факультет радіофізики, електроніки та комп'ютерних систем, \\ вул. Володимирсъка, 60, Київ, 01033, Україна
}

\begin{abstract}
Розглянуто реконструкцію томограм для різних часових параметрів послідовності. Для відповідних часових параметрів знайдено параметри чутливості до зважування за дифузією води. Представлено реконструйовані томограми та окремі фрагменти томограм, зважені за параметрами чутливості до дифузії, що відповідають різним часовим параметрам. Запропоновано фільтрацію зважених томограм за параметром чутливості з використанням методу матриці Гаусса з відповідними параметрами.
\end{abstract}

